\title{
Leisure Boredom Scale: A Research on University Students
}

\author{
Abdulmenaf Korkutata \\ Correspondence: Abdulmenaf Korkutata, Çanakkale OnSekiz Mart University, Çanakkale, Turkey. \\ Received: September 25, 2018 \\ Accepted: October 25, $2018 \quad$ Online Published: October 25, 2018 \\ doi:10.11114/jets.v6i12.3648 \\ URL: https://doi.org/10.11114/jets.v6i12.3648
}

\begin{abstract}
The aim of this research was to review the leisure boredom perceptions of students who study in the faculty of sports sciences by different variables. 1223 students voluntarily participated in this research. These students study in the faculty of sports sciences in three universities in Turkey and they were selected by random sampling method. 367 of participants were female (30\%); $856(70 \%)$ of participants were males. Leisure boredom scale (LBS) that was developed by Iso-Ahola and Weissinger (1990) was used in this research to collect the data. Kara, Gürbüz, and Öncü (2014) adapted this scale into Turkish. Besides, an information form that includes socio-demographic attributes was asked participants to fill. T-test, ANOVA test and descriptive statistical methods analyzed the data. While there was found a statistically significant difference $(\mathrm{p}<0,05)$ in boredom sub-dimension in terms of gender variable, there was no statistically significant difference in satisfaction sub-dimension. About the monthly income variable, a statistically significant difference $(\mathrm{p}<0,05)$ was observed in both boredom and satisfaction sub-dimensions. However, there was no statistically significant difference $(p>0,05)$ in leisure boredom perception based on the age variable.
\end{abstract}

Keywords: Leisure, boredom perception, the university student

\section{Introduction}

There are periods that people use to satisfy the needs and also use for optional needs (Ardahan et al., 2016). With reference to another definition, there are periods in which people voluntarily participate in activities to renew and have fun after performing the obligatory activities (Cordes, 2013). It is inarguable that there also are optional times that people can spend in line with their desires have a goal; again, this circumstance provides the lives of individuals to be more productive (Iwasaki, 2007). People may face problems in leisure times; boredom perception is one of the most remarkable of these problems (Iso-Ahola \& Weissinger, 1990). According to the literature, boredom is cases such as distortion of focus, lack of interest and negative mood arises in person during the activity (McCormick et al., 2005; Pekrun et al., 2010; Vogel-Walcutt et al., 2012). Another expression defines boredom as follows; boredom is a subjective perception status as the result of becoming leisure time activities like a rutin by not giving a pleasure enough (Iso-Ahola and Weissinger, 1990). Namely, if the person is not sufficiently stimulated in the current situation, he/she can be exposed to the feeling of dissatisfaction and boredom (Brissett and Snow, 1993). It is also be thought that boredom arises in leisure time; the leisure time activities may be meaningless (Van Tilburg and Igou, 2012). With reference to the results of some of the surveys, individuals face with bad habits (alcohol consumption, substance use) and health problems as the result of boredom (Wiesner et al., 2005; Anshel, 1991; Thackray, 1981). Thus, it is known that the section in society who has the most leisure time is the students (Ragheb and Merydith, 2001). It is an expected result that students attach more importance to leisure time in comparison with adults (Mansuroğlu, 2002). Students may fall into bad habits because of boredom; this situation restricts them to participate in sports and leisure time activities (Biolcati et al., 2018), even negatively affects their academic success (Pekrun et al., 2002). Moreover, the boredom level of students in leisure time is more than the boredom level of other people in different occupational groups (Spruyt et al., 2018).

Accordingly, the fact that the section who is mostly exposed to the positive and negative effects of boredom in leisure times makes think that this issue can be researched on the students in the most efficient way. So and so, there are studies that scrutinize the attributes of leisure time activities that cause boredom and avoid boredom (Caldwell et al.,1999; Torkildsen, 2006; Karaküçük and Akgül, 2016; Çetiner and Yayla, 2017; İskender and Güçer, 2018).

It is thought that the fountainhead of boredom is to misuse the leisure times. In conclusion, this research expresses that students should use their leisure time properly; otherwise, they will be exposed to the negative effects of the boredom. Students can keep their psychological and social conditions by making the right choice on leisure time activities and 
being busy with an activity, above all. The thought that students are building blocks of the future reveals the necessity of directing them properly. Accordingly, keeping their psychological and sociological well-being is essential. Therefore, this research will contribute to the literature and lead the way to educators on the issue of guiding students.

\section{Method}

The goal of this research was to review leisure boredom perceptions of students study in faculties of sports sciences. The questionnaire technique was performed by students one-for-one by random sampling method.

Participants: Entirely 1223 students whose 367 (30\%) were female and 856 (70\%) were male voluntarily participated in this research. The questionnaire form was applied in 1350 students who study in faculties of sports sciences in a classroom environment by making required statements. 1230 of questionnaire form were collected; 120 of the forms that were not proper for analysis were excluded from the research because of the lack of data. 367 female and 856 male students voluntarily participated in the research; entirely 1223 questionnaire form was subjected to the analysis.

Data Collection Tool: There are personal information about gender, income, university, department, grade, and age in socio-demographic attributes form; a questionnaire form was constituted by adding leisure boredom scale besides these personal information form. Leisure Boredom Scale (LBS): This scale was developed by Iso-Ahola and Weissinger (1990) to measure personal differences in boredom perceived in leisure times. The original scale is unidimensional and composed of 16 items. The scale consists of 5 Likerts; ' $1=$ Strongly disagree' ' $2=$ Strongly agree'. Kara, Gürbüz, and Öncü (2014) actualized validity and reliability study of the original scale. The adapted scale has been applied in grown-ups in several occupational groups. A number of expressions are 16; this number degraded to 10 in an adapted version. There are two sub-dimensions in the scale. 'Boredom' sub-dimension reflects the negative point of view against leisure time activities (I usually do not like things what I do in leisure times, but I do not know what else to do). 'Satisfaction' sub-dimension reflects the positive point of view in perceiving the leisure time (The idea of leisure time excites me).

Validity, Reliability: Cronbach Alpha reliability coefficient in the original study was found respectively as $0,85,0,88$ and 0,86 on different sample groups. Internal consistency values of points that were received from sub-dimensions of Turkish reliability and validity study of the scale were 0,72 for boredom, 0,77 for satisfaction (Kara, Gürbüz and Öncü, 2014). In our research, boredom sub-dimension was computed as 0,72 ; satisfaction sub-dimension was computed as 0,69 . Factor analysis was applied in the scale to review the construct validity of the research. It is observed that the original scale has the same factor structure with this research; namely, it is composed of 2 dimensions.

Data analysis: Statistical analyses within the research were performed by SPSS 23 statistics packaged software. Descriptive statistics, T-test and ANOVA analyzed the data. Normality test was applied to test the distributions of data before analyzing and commenting on the findings. It is seen at the end of reviewing similar studies in the literature that skewness and kurtosis values bear the normality assumption (Brown, 2011; Tabachnick et al., 2013). Besides, according to our acception in line with the literature, since the data are of value between -2 and +2 , the data display normal distribution (Skewness: 0,201; Kurtosis: 0,542).

Research Question: This research analyzed the demographic attributes and boredom perception of students study faculty of sports sciences. Within this context, we sought an answer to the research question below.

Does the leisure boredom perception of students who study in faculties of sports sciences vary by different variables? Below hypotheses were tested based on the research question.

Research Hypothesis

$\mathrm{H}_{0}$ : There is no difference between leisure boredom perception and different socio-demographic attributes of university students.

$\mathrm{H}_{1}$ : There is a difference between leisure boredom perception and different socio-demographic attributes of university students.

\section{Sub-Hypotheses}

$\mathrm{H}_{1}$ : There is a significant difference between sub-dimensions of leisure boredom perceptions of students who study in the faculty of sports based on gender variable.

$\mathrm{H}_{2}$ : There is a significant difference between sub-dimensions of leisure boredom perception of students who study in the faculty of sports sciences based on the gender variable.

$\mathrm{H}_{3}$ : There is a significant difference between leisure boredom perceptions of students who study in the faculty of sports sciences based on the income status variable.

$\mathrm{H}_{4}$ : There is a significant difference between sub-dimensions of leisure boredom perception of students who study in the 
faculty of sports sciences based on income status variable.

$\mathrm{H}_{5}$ : There is a significant difference between leisure boredom perception of students who study in the faculty of sports sciences based on university variable.

$\mathrm{H}_{6}$ : There is a significant difference between sub-dimensions of leisure boredom perception of students who study in the faculty of sports sciences based on university variable.

$\mathrm{H}_{7}$ : There is a significant difference between leisure boredom perception of students who study in the faculty of sports sciences based on the department variable.

$\mathrm{H}_{8}$ : There is a significant difference between sub-dimensions of leisure boredom perception of students who study in the faculty of sports sciences based on the department variable.

$\mathrm{H}_{9}$ : There is a significant difference between leisure boredom perception of students who study in the faculty of sports sciences based on grade (class) variable.

$\mathrm{H}_{10}$ : There is a significant difference between sub-dimensions of leisure boredom perceptions of students who study in the faculty of sports sciences based on grade (class) variable.

$\mathrm{H}_{11}$ : There is a significant difference between leisure boredom perception of students who study in the faculty of sports sciences based on age variable.

$\mathrm{H}_{12}$ : There is a significant difference between sub-dimensions of leisure boredom perception of students who study in the faculty of sports sciences based on age variable.

\section{Results}

Below tables show the findings that are obtained by analyzing the data of students who participated in the research

Table 1. Demographic Information

\begin{tabular}{llllll}
\hline GENDER & $\mathrm{N}$ & $\%$ & UNIVERSITY & $\mathrm{N}$ & $\%$ \\
\hline Female & 367 & 30 & Sakarya University & 387 & 31,6 \\
Male & 856 & 70 & Kütahya Dumlupinar University & 394 & 32,2 \\
Total & 1223 & 100 & Çanakkale Onsekiz Mart University & 442 & 36,2 \\
INCOME & $\mathrm{N}$ & $\%$ & Total & 1223 & 100 \\
600 TL and less & 476 & 38,9 & DEPARTMENT & $\mathrm{N}$ & $\%$ \\
601 TL-1000 TL & 376 & 30,7 & Teachership & 285 & 23,3 \\
1001 TL-1500 TL & 216 & 17,7 & Management & 443 & 36,2 \\
1501 TL and more & 155 & 12,7 & Recreation & 213 & 17,4 \\
Total & 1223 & 100 & Coaching & 282 & 23,1 \\
AGE & $\mathrm{N}$ & $\%$ & Total & 1223 & 100 \\
$18-19$ & 214 & 17,5 & GRADE & $\mathrm{N}$ & $\%$ \\
$20-21$ & 544 & 44,5 & 1st Grade & 471 & 38,5 \\
$22-23$ & 307 & 25,1 & 2nd Grade & 269 & 22,0 \\
24 years and older & 158 & 12,9 & 3rd Grade & 302 & 24,7 \\
& & & 4 th Grade & 181 & 14,8 \\
Total & 1223 & 100 & Total & 1223 & 100 \\
\hline & & & (T)
\end{tabular}

It is seen when looking at demographic information (Table 1) of participants that the highest number belongs to male students (N: 856). About the age averages, $44,5 \%$ of the students were in the $20-21$ age group. A clear majority of participants have income at the level of $600 \mathrm{TL}$ and less (N: 476). The number of students who study in the management department is higher in comparison with the number of students study in other departments. About the university 
department, the highest participation was provided by Çanakkale Onsekiz Mart University (36,2\%). Moreover, the highest number in grade variable belongs to students who study in the 1 st grade.

Table 2. Difference Between Total Scores of Leisure Boredom Perception (LBP) and Sub-Dimensions of Leisure Boredom Perception (LBP) Based on Gender Variable

\begin{tabular}{lllllll}
\hline Scale & Gender & $\mathrm{N}$ & $\mathrm{X}$ & $\mathrm{SD}$ & $\mathrm{t}$ & $\mathrm{p}$ \\
\hline \multirow{2}{*}{ LBP } & Female & 367 & 30,76 & 5,129 & & \\
& Male & 856 & 31,32 & 5,621 & & \\
\hline \multirow{2}{*}{ Boredom } & Female & 367 & 12,88 & 4,783 & & 0,103 \\
& Male & 856 & 13,60 & 4,657 & & \\
& Female & 367 & 17,88 & 3,945 & 0,015 \\
\multirow{2}{*}{ Satisfaction } & Male & 856 & 17,72 & 3,802 & 0,664 & 0,507 \\
& & & & & \\
& & & & & & \\
\end{tabular}

Since the Levene test did not found a significant difference between variances of two group averages, the variances were found as homogeneous. Since Levene test significance level is higher than 0,05 ( $p<0,103)$, there is no difference between variances of females and males. Accordingly, there is not a significant difference between leisure boredom perceptions of females and males $\left(\mathrm{t}_{(1221)}=-1,630, \mathrm{p}=0,103>0,05\right)$. Therefore, $\mathrm{H}_{1}$ hypothesis called ' There is a significant difference between leisure boredom perceptions of students who study in the faculty of sports based on gender variable" is denied.

T-Test analysis that was performed between gender and leisure boredom perception dimension found a significant difference in boredom dimension from leisure boredom perception sub-dimensions $\left(\mathrm{t}_{(1221)}=-2,446, \mathrm{p}=0,015<0,05\right)$. Since the average values of males $(\mathrm{X}: 13,60)$ were higher than the average values of females $(\mathrm{X}: 12,88)$, boredom state of males from the leisure time activities was higher than boredom state of females from the leisure time activities. There is a significant difference between genders based on satisfaction dimension in leisure boredom perception $\left(\mathrm{t}_{(1221)}=0,664\right.$, $\mathrm{p}=0,507>0,05)$. Accordingly, $\mathrm{H}_{2}$ hypothesis called "There is a significant difference between sub-dimensions of leisure boredom perception of students who study in the faculty of sports sciences based on the gender variable" is denied.

Table 3. Difference Between Leisure Boredom Perception total Score and Sub-Dimensions of Leisure Boredom Perception

\begin{tabular}{|c|c|c|c|c|c|c|c|}
\hline Scale & Income & $\mathrm{N}$ & $\mathrm{X}$ & SS & $\mathrm{F}$ & $\mathrm{P}$ & Difference \\
\hline \multirow{4}{*}{ LBP } & $600 \mathrm{TL}$ and Less & 475 & 31,18 & 5,548 & \multirow{4}{*}{2,548} & \multirow{4}{*}{0,054} & \multirow{4}{*}{-} \\
\hline & $601 \mathrm{TL}-1000 \mathrm{TL}$ & 375 & 30,60 & 5,194 & & & \\
\hline & $1001 \mathrm{TL}-150 \mathrm{TL}$ & 216 & 31,51 & 5,279 & & & \\
\hline & $1501 \mathrm{TL}$ and More & 155 & 31,90 & 6,113 & & & \\
\hline \multirow{4}{*}{ Boredom } & $600 \mathrm{TL}$ and Less & 476 & 13,64 & 4,773 & \multirow{4}{*}{2,989} & \multirow{4}{*}{0,030} & \multirow{4}{*}{-} \\
\hline & 601 TL-1000 TL & 376 & 12,97 & 4,494 & & & \\
\hline & 1001 TL-150 TL & 216 & 13,05 & 4,616 & & & \\
\hline & 1501 TL and More & 155 & 14,09 & 5,017 & & & \\
\hline \multirow{4}{*}{ Satisfaction } & $600 \mathrm{TL}$ and Less & 476 & 17,55 & 3,906 & \multirow{4}{*}{3,049} & \multirow{4}{*}{0,028} & \multirow{4}{*}{$3-1$} \\
\hline & $601 \mathrm{TL}-1000 \mathrm{TL}$ & 376 & 17,64 & 3,812 & & & \\
\hline & $1001 \mathrm{TL}-1500 \mathrm{TL}$ & 216 & 18,46 & 3,671 & & & \\
\hline & $1501 \mathrm{TL}$ and More & 155 & 17,81 & 3,895 & & & \\
\hline
\end{tabular}

Groups: 1=600 TL and Less 2=601 TL-1000 TL 3=1001 TL-1500 TL 4=1501 TL and More

ANOVA analysis did not find a significant difference between income status and leisure boredom perception $\left(\mathrm{F}_{(3)}=2,548\right.$, $\mathrm{p}=0,054>0,05)$. With reference to $\mathrm{H}_{3}$ hypothesis called "There is a significant difference between leisure boredom perceptions of students who study in the faculty of sports sciences based on the income status variable" is denied. 
ANOVA analysis was performed between income status and boredom dimension from sub-dimensions of leisure boredom perception; there was observed a significant difference at the end of the analysis $\left(F_{(3)}=2,989, p=0,030<0,05\right)$. Tukey and Scheffe tests were used to determine the source of the difference. The source of the difference could not be found at the end of the analysis. Since the values between the groups are higher than $\mathrm{p}<0,05$, the difference between the groups could not be revealed.

ANOVA analysis was performed between income status and satisfaction dimension from sub-dimensions of leisure boredom perception; there was found a significant difference at the end of the analysis $\left(F_{(3)}=3,049, p=0,028<0,05\right)$. Tukey and Scheffe tests from Post Hoc tests were utilized to specify the source of the difference. There was observed a significant difference between students who have $600 \mathrm{TL}$ and less income and students who have an income between 1001-1500 TL. Leisure boredom perception of students at the group of " 600 TL and less" is lower in comparison with the students at the group of "1001-1500 TL" (X: $600 \mathrm{TL}$ and less=17,55; X:1001-1500 TL =18,46). Therefore, the $\mathrm{H}_{4}$ hypothesis called "There is a significant difference between sub-dimensions of leisure boredom perception of students who study in the faculty of sports sciences based on income status variable" is accepted.

Table 4. Difference Between Leisure Boredom Perception Total Score and Sub-Dimensions of Leisure Boredom Perception based on University Variable

\begin{tabular}{|c|c|c|c|c|c|c|c|c|c|}
\hline Scale & University & & & $\mathrm{N}$ & $\mathrm{X}$ & $\mathrm{Sd}$ & $\mathrm{F}$ & $\mathrm{P}$ & Difference \\
\hline \multirow{3}{*}{ LBP } & Sakarya Un & sity & & 387 & 31,73 & 5,416 & \multirow{3}{*}{6,124} & \multirow{3}{*}{0,002} & \multirow{3}{*}{$1-3,2-3$} \\
\hline & \multicolumn{3}{|c|}{ Kütahya Dumlupınar University } & 394 & 31,73 & 5,916 & & & \\
\hline & $\begin{array}{l}\text { Çanakkale } \\
\text { University }\end{array}$ & Onsekiz & Mart & 442 & 30,45 & 5,056 & & & \\
\hline \multirow{3}{*}{ Boredom } & \multicolumn{3}{|c|}{ Sakarya University } & 387 & 13,99 & 4,593 & \multirow{3}{*}{6,896} & \multirow{3}{*}{0,001} & \multirow{3}{*}{$1-3$} \\
\hline & \multicolumn{3}{|c|}{ Kütahya Dumlupınar University } & 394 & 13,45 & 4,842 & & & \\
\hline & $\begin{array}{l}\text { Çanakkale } \\
\text { Univiversity }\end{array}$ & Onsekiz & Mart & 442 & 12,79 & 4,615 & & & \\
\hline \multirow{3}{*}{ Satisfaction } & \multicolumn{3}{|c|}{ Sakarya University } & 387 & 13,99 & 4,593 & \multirow{3}{*}{0,481} & \multirow{3}{*}{0,618} & \multirow{3}{*}{-} \\
\hline & \multicolumn{3}{|c|}{ Kütahya Dumlupınar University } & 394 & 13,45 & 4,842 & & & \\
\hline & $\begin{array}{l}\text { Çanakkale } \\
\text { University }\end{array}$ & Onsekiz & Mart & 442 & 12,79 & 4,615 & & & \\
\hline
\end{tabular}

Groups: 1=Sakarya University 2=Kütahya Dumlupınar University 3=Çanakkale Onsekiz Mart University

A significant difference was observed between university variable and leisure boredom $\left(\mathrm{F}_{(2)}=6,124, \mathrm{p}=0,002<0,05\right)$. Tukey test from Post Hoc tests was applied to reveal the group that this difference centers on. A significant difference was found between all the groups at the end of Tukey test. Leisure boredom average values of students who study in Sakarya University (X: 31,73) and Kütahya Dumlupınar University (X: 31,37) are higher than the average values of students who study in Çanakkale Onsekiz Mart University (X: 30,45). In this regard, the $\mathrm{H}_{5}$ hypothesis called 'There is a significant difference between leisure boredom perception of students who study in the faculty of sports sciences based on university variable" is accepted.

The difference between university variable and leisure boredom sub-dimensions was reviewed; a significant difference was found at the end of this review $\left(\mathrm{F}_{(2)}=6,896, \mathrm{p}=0,001<0,05\right)$. A significant difference was found in boredom dimension as well $\left(\mathrm{F}_{(2)}=6,896, \mathrm{p}=0,001<0,05\right)$. There was no difference in satisfaction dimension $\left(\mathrm{F}_{(2)}=0,481\right.$, $\mathrm{p}=0,618>0,05)$. Tukey test from Post Hoc tests was performed to find the group includes the difference. It is seen that boredom average values of students of faculty of sports sciences in Sakarya University (X: 13,99) are higher than the boredom average values of students of faculty of sports sciences in Çanakkale Onsekiz Mart University (X: 12,79). With reference to this result, the $\mathrm{H}_{6}$ hypothesis called "There is a significant difference between sub-dimensions of leisure boredom perception of students who study in the faculty of sports sciences based on university variable" is accepted. 
Table 5. Difference Between Leisure Boredom Perception Total Score and Sub-Dimensions of Leisure Boredom Perception based on Department Variable

\begin{tabular}{lllllll}
\hline Scale & Departments & N & X & Sd & F & P \\
\hline \multirow{4}{*}{ LBP } & Teachership & 285 & 31,46 & 5,581 & & \\
& Management & 443 & 31,00 & 5,303 & & \\
& Recreation & 213 & 31,82 & 5,886 & 2,483 & 0,059 \\
& Coaching & 282 & 30,59 & 5,293 & & \\
\multirow{3}{*}{ Boredom } & Teachership & 285 & 13,85 & 4,657 & & \\
& Management & 443 & 13,22 & 4,797 & & \multirow{2}{*}{0,162} \\
& Recreation & 213 & 13,56 & 4,837 & & \\
& Coaching & 282 & 13,04 & 4,482 & & \\
\multirow{3}{*}{ Satisfaction } & Teachership & 285 & 17,61 & 3,800 & & \\
& Management & 443 & 17,77 & 3,965 & 1,649 & 0,176 \\
& Recreation & 213 & 18,26 & 3,863 & & \\
& Coaching & 282 & 17,55 & 3,666 & & \\
\hline
\end{tabular}

The difference between leisure boredom perception of students who study in the faculty of sports sciences based on departments was analyzed. There was no difference between departments and leisure boredom perception $\left(\mathrm{F}_{(3)}=2,483\right.$, $\mathrm{p}=0,059>0,05)$. With reference to this result, $\mathrm{H}_{7}$ hypothesis called There is a significant difference between leisure boredom perception of students who study in the faculty of sports sciences based on the department variable" is denied.

The difference between sub-dimensions of leisure boredom perception of departments in the faculties of sports sciences was analyzed; there was not found a significant difference between departments and sub-dimensions at the end of the analysis (Boredom: $F_{(3)}=1,717, p=0,162>0,05$; Satisfaction: $F_{(3)}=1,649, p=0,176>0,05$ ). With reference to this conclusion, $\mathrm{H}_{8}$ hypothesis called "There is a significant difference between sub-dimensions of leisure boredom perception of students who study in the faculty of sports sciences based on the department variable" is denied.

Table 6. Difference Between Leisure Boredom Perception Total Score and Sub-Dimensions of Leisure Boredom Perception based on Grade Variable

\begin{tabular}{lllllll}
\hline Scale & Grades & N & X & Sd & F & P \\
\hline \multirow{3}{*}{ LBP } & 1st Grade & 471 & 31,15 & 5,538 & & \\
& 2nd Grade & 269 & 30,86 & 5,260 & & \\
& 3rd Grade & 302 & 31,18 & 5,205 & 0,557 & 0,643 \\
& 4th Grade & 181 & 31,54 & 6,091 & & \\
\hline \multirow{3}{*}{ Boredom } & 1st Grade & 471 & 13,45 & 4,664 & & \\
& 2nd Grade & 269 & 13,54 & 4,686 & & \\
& 3rd Grade & 302 & 13,17 & 4,594 & 0,351 & 0,788 \\
& 4th Grade & 181 & 13,35 & 5,037 & & \\
\hline \multirow{3}{*}{ Satisfaction } & 1st Grade & 471 & 17,70 & 3,951 & & \\
& 2nd Grade & 269 & 17,32 & 3,906 & & \\
& 3rd Grade & 302 & 18,02 & 3,667 & & \\
& 4th Grade & 181 & 18,19 & 3,714 & & \\
\hline
\end{tabular}


The difference in leisure boredom perception based on grades was analyzed. There was no significant difference between grades and leisure boredom perception $\left(\mathrm{F}_{(3)}=0,557, \mathrm{p}=0,643>0,05\right)$. Therefore, $\mathrm{H}_{9}$ hypothesis called 'There is a significant difference between leisure boredom perception of students who study in the faculty of sports sciences based on grade (class) variable" is denied.

The difference between leisure boredom perception sub-dimensions of departments in the faculties of sports sciences in universities was analyzed; a significant difference was not found between departments and sub-dimensions at the end of the analysis (Boredom: $F_{(3)}=0,351, p=0,788>0,05$; Satisfaction: $F_{(3)}=2,432, p=0,064>0,05$ ). Therefore, $H_{10}$ hypothesis called "There is a significant difference between sub-dimensions of leisure boredom perceptions of students who study in the faculty of sports sciences based on grade (class) variable" is denied.

Table 7. Difference Between Leisure Boredom Perception Total Score and Sub-Dimensions of Leisure Boredom Perception based on Age Variable

\begin{tabular}{|c|c|c|c|c|c|c|}
\hline Scale & Age & $\mathrm{N}$ & $\mathrm{X}$ & $\mathrm{Sd}$ & $\mathrm{F}$ & $\mathrm{P}$ \\
\hline \multirow{4}{*}{ LBP } & $18-19$ & 214 & 30,95 & 5,264 & \multirow{4}{*}{0,573} & \multirow{4}{*}{0,633} \\
\hline & $20-21$ & 544 & 31,38 & 5,373 & & \\
\hline & $22-23$ & 307 & 30,95 & 5,216 & & \\
\hline & 24 years and older & 158 & 31,04 & 6,564 & & \\
\hline \multirow{4}{*}{ Boredom } & $18-19$ & 214 & 13,30 & 4,666 & \multirow{4}{*}{0,949} & \multirow{4}{*}{0,416} \\
\hline & $20-21$ & 544 & 13,58 & 4,677 & & \\
\hline & $22-23$ & 307 & 13,36 & 4,518 & & \\
\hline & 24 years and older & 158 & 12,87 & 5,189 & & \\
\hline \multirow{4}{*}{ Satisfaction } & $18-19$ & 214 & 17,65 & 4,188 & \multirow{4}{*}{0,872} & \multirow{4}{*}{0,455} \\
\hline & $20-21$ & 544 & 17,80 & 3,726 & & \\
\hline & $22-23$ & 307 & 17,59 & 3,814 & & \\
\hline & 24 years and older & 158 & 18,16 & 3,827 & & \\
\hline
\end{tabular}

The difference between leisure boredom perception based on the age variable was analyzed. A significant difference was not found at the end of the analysis $\left(\mathrm{F}_{(3)}=0,573, \mathrm{p}=0,633>0,05\right)$. With reference to this conclusion, $\mathrm{H}_{11}$ hypothesis called "There is a significant difference between leisure boredom perception of students who study in the faculty of sports sciences based on age variable" is denied.

The difference between the sub-dimensions of leisure boredom perception was reviewed. No significant difference was found between age and sub-dimensions (Boredom: $\mathrm{F}_{(3)}=0,949, \mathrm{p}=0,416>0,05$; Satisfaction: $\mathrm{F}_{(3)}=0,872, \mathrm{p}=0,455>0,05$ ). With reference to this conclusion, $\mathrm{H}_{12}$ hypothesis called "There is a significant difference between sub-dimensions of leisure boredom perception of students who study in the faculty of sports sciences based on age variable" is denied.

\section{Discussion}

There was not found a statistically significant difference as the result of the analysis that was performed to reveal the difference between gender and leisure boredom perceptions of the students $\left(\mathrm{t}_{(1221)}=-1,630, \mathrm{p}=0,103>0,05\right)$. In the doctorate study of Kara (2015), Leisure Boredom Perception Scale was applied in 724 married people and there was not seen a difference between the genders. Thus, findings of this research show parallelism with the literature (Pillai's Trace $\left.=0,00, \mathrm{~F}_{(2,715)}=0,437, \mathrm{p}=0,64>0,05\right)$. However, Newberry and Duncan (2001) determined a different result in the research conducted on 418 high-schoolers about boredom $\left(\mathrm{F}_{(1,402)}=10,28, \mathrm{p}=0,001<0,05\right)$. Besides, the average points of the male were found as higher than the average points of the females (Males: $\mathrm{M}=14,95$, $\mathrm{SD}=3,36$; Females: $\mathrm{M}=13,82$, $\mathrm{SD}=3,64)$

While there was a difference in boredom dimension in comparison of gender and leisure boredom perception $\left(\mathrm{t}_{(1221)}=-2,446, \mathrm{p}=0,015<0,05\right)$, there was no difference in satisfaction dimension $\left(\mathrm{t}_{(1221)}=0,664, \mathrm{p}=0,507>0,05\right)$. The difference in boredom dimension was higher in males $(\mathrm{X}: 13,60)$ than the females $(\mathrm{X}: 12,88)$. So and so, it is possible to 
say that boredom state of men from the leisure time activities is higher than the boredom state of women from the leisure time activities. Kara and Ayverdi (2018) conducted a study on the reasons for using alcohol in leisure time of 229 students study in faculties of sports sciences in different universities in Ankara. They applied an analysis to reveal the difference between gender and leisure boredom perception; a significant difference was found in boredom dimension $(\mathrm{p}=0,008<0,05)$. It can be said in line with this result that leisure boredom values of male students $(\mathrm{N}=151, \mathrm{X}$ : $2,49)$ are higher than the leisure boredom values of female students $(N=78, X: 2,23)$; however, there is no difference in satisfaction dimension $(\mathrm{p}=0,342>0,05)$. So, the findings of the research mentioned jibe with our research results.

It is determined that there is no significant difference in the comparison of income variable and leisure boredom perception $\left(\mathrm{F}_{(3)}=2,548, \mathrm{p}=0,054>0,05\right)$. Therefore, it is possible to mention that income is not a determinant in terms of leisure boredom perception. Yaşartürk et al., performed a survey on 639 students in 2017 to review the difference between leisure boredom perception based on the income variable. There was not seen statistically significant difference towards leisure boredom perception based on income variable $\left(\mathrm{F}_{(6)} 0,687, \mathrm{p}=0,660>0,05\right)$.

A significant difference was observed in both two dimensions in the comparison of income variable and leisure boredom perception (Boredom $=\mathrm{F}_{(3)}=2,989, \mathrm{p}=0,030<0,05$; satisfaction $=\mathrm{F}_{(3)}=3,049, \mathrm{p}=0,028<0,05$ ). Tukey test was applied to determine the source of the difference in boredom dimension. However since the values were less than 0,05 , the source of the difference could not be found. In satisfaction dimension, the students who have $600 \mathrm{TL}$ and less $(X:=17,55)$ income have higher average values than the students whose income is between 601-1500 TL $(X=18,46)$. According to this conclusion, the satisfaction level of students whose income is between 601-1500 TL is higher than the satisfaction level of students whose income is $600 \mathrm{TL}$ and less. It is understood by the findings above, income has importance in making use of leisure time well by participating in fun activities.

Yaşartürk et al., (2017) performed a study on 639 students in the school of physical education and sports in Bartın University. While they find a statistically significant difference in boredom dimension based on income variable $\left.F_{(6)} 2,450, p=0,024<0,05\right)$, there is no statistically significant difference $(p>0,05)$ in satisfaction dimension $\left(F_{(6)} 1,675\right.$, $\mathrm{p}=0,125>0,05)$. The difference in the level of income is between participants whose income is $1101 \mathrm{TL}$ and more and participants whose income is $400 \mathrm{TL}$ and less. Since the students whose income level is high consistently perform the same activities, it can be said that the high level of income does not change dissatisfaction and lack of motivation. Because, they thought that the increase in the level of income constitutes the continuity, not variedness.

There was found a significant difference between university variable and leisure boredom perception of students $\left(F_{(2)}=6,124, p=0,002<0,05\right)$. Tukey test was applied to reveal the group that the difference is centered upon. Tukey test found a significant difference between all the groups. Average values of leisure boredom perception of students of faculty of sports sciences in the 1st (X: 31,73) and the 2nd group (X: 31,37) are higher than average values of leisure boredom perception of students of faculty of sports sciences in the 3rd group (X: 30,45). The difference between university variable and leisure boredom perception sub-dimensions of students was reviewed. While a significant difference was determined in boredom dimension $\left(\mathrm{F}_{(2)}=6,896, \mathrm{p}=0,001<0,05\right)$, there was not found a significant difference in satisfaction dimension $\left(\mathrm{F}_{(2)}=0,481, \mathrm{p}=0,618>0,05\right)$. Tukey test was applied to find the source of the difference. According to the analysis results, boredom dimension average values of students of faculty of sports sciences in Sakarya University (X: 13,99) is higher than boredom dimension average values of students of faculty of sports sciences in Çanakkale Onsekiz Mart University (X: 12,79).

We have not encountered with literature studies in which comparisons are made to measure the leisure boredom perception; however, there is seen analyses performed by different variables (Pekrun et al., 2010; Yaşartürk et al., 2017; Spruyt et al., 2018; Kara, 2015; Kara and Gücal, 2016, Kara et al., 2017; Yaşartürk, 2016; Öner, 2017; Kara and Özdedeoğlu, 2017; Kara and Ayverdi, 2018; Van Tilburg and İgou, 2012; Ragheb and Merydith, 2001). Accordingly, we could not make evaluations with different studies in the conclusion part.

It is determined whether there is a significant difference between leisure boredom perception based on departments. There is no significant difference between departments and leisure boredom perception $\left(F_{(3)}=2,483, p=0,059>0,05\right)$. With reference to the research of Yaşartürk et al., (2017), there is not a significant difference in leisure boredom perception based on department variable $\left(\mathrm{F}_{(3)}=0,380, \mathrm{p}=767>0,05\right)$. Moreover, the difference between sub-dimensions of leisure boredom perception of departments in the faculty of sports sciences was analyzed. No significant difference was seen between the departments and sub-dimensions (Boredom: $F_{(3)}=1,717, p=0,162>0,05$; Satisfaction: $F_{(3)}=1,649$, $\mathrm{p}=0,176>0,05)$. Yaşartürk et al., (2017) pointed put that there is not a statistically significant difference between boredom $\left(\mathrm{F}_{(3)}=1,587, \mathrm{p}=0,191>0,05\right)$ and satisfaction dimensions $\left(\mathrm{F}_{(3)}=1,674, \mathrm{p}=0,171>0,05\right)$. Thus, the results jibe with our research results.

A study was conducted to find the difference between leisure boredom perception based on the grades variable $\left(F_{(3)}=0,557, p=0,643>0,05\right)$. There is not observed a significant difference between grades and leisure boredom 
perception $\left(\mathrm{F}_{(3)}=0,557, \mathrm{p}=0,643>0,05\right)$.

There was not found a significant difference between grades and sub-dimensions (Boredom: $F_{(3)}=0,351, p=0,788>0,05$; Satisfaction: $\left.\mathrm{F}_{(3)}=2,432, \mathrm{p}=0,064>0,05\right)$. Kara et al., (2017) pointed out that there is not a significant difference ( $>0,05)$ between leisure boredom perception based on the grade variable. Results of Kara et al., (2017) jibe with our results when the fewness of studies on grade variable is considered.

It is determined when looking at whether there is a difference between age and boredom perception that there is no significant difference between age and leisure boredom perception $\left(\mathrm{F}_{(3)}=0,573, \mathrm{p}=0,633>0,05\right)$. In conclusion, the negative point of view against the leisure time activities of male students is higher than the negative point of view against the leisure time activities of female students. Following items can be thought of as the reasons for this circumstance; limited economic freedom of young; individual differences, and other similar variables. The difference in income state stems from being worked in the private sector after school time. Another assumption on this issue is that income state of students is based on the support of families. The reason for the difference in age variable is that the ages of students are close to each other; they participate in similar activities in provinces they live in. The reason for the difference in university variable may be that the geographical position of their universities is reachable. About the grade and departments, the difference may stem from the same school environment they share.

\section{References}

Anshel, M. H. (1991). A survey of elite athletes on the perceived causes of using banned drugs in sport. Journal of Sport Behavior, 14, 283.

Ardahan, F., Turgut, T., \& Kalkan, A. (2016). Recreation in all aspects. Detail Publishing, Ankara.

Biolcati, R., Mancini, G., \& Trombini, E. (2018). Proneness to Boredom and Risk Behaviors During Adolescents' Free Time. Psychological Reports: SAGE Journal, 121(2), 303-323. https://doi.org/10.1177/0033294117724447

Brissett, D., \& Snow, R. P. (1993). Boredom: Where the future isn't. Symbolic Interaction, 16, 237-256. https://doi.org/10.1525/si.1993.16.3.237

Brown, S. (2011). Measures of Shape: Skewness and Kurtosis. Oak Road Systems. https://brownmath.com/stat/shape.htm (Erişim tarihi:15.07.2018).

Caldwell, L. L., Darling, N., Payne, L. L., \& Dowdy, B. (1999). Why are you bored? An examination of psy-chological and social control causes of boredom among adolescents. Journal of Leisure Research, 31, 103- 121. https://doi.org/10.1080/00222216.1999.11949853

Çetiner, H., \& Yayla, Ö. (2017). "Research on the Attitudes of Undergraduate Tourism Students Towards Animator Profession". Journal of Recreation and Tourism Research, 4(3), 1-12.

Cordes, K. A. (2013). Applications in Recreation \& Leisure: For today and the future. Urbana, Illinois: Sagamore publishing, L.L.C..

İskender, A., \& Güçer, E. (2018). Determining the relationship between perceived boredom and dodgy behaviors: An practice on university students. Tourism Academic Journal, 5(1), 86-97.

Iso-Ahola, S., \& Weissinger, E. (1990). Perceptions of boredom in leisure: conceptualization, reliability and validity of the leisure boredom scale. Journal of Leisure Research, 22(1), 1-17. https://doi.org/10.1080/00222216.1990.11969811

Iwasaki, Y. (2007). Leisure and quality of life in an international and multicultural context: what are major pathways linking leisure to quality of life. Social Indicators Research, 82(2), 233-264. https://doi.org/10.1007/s11205-006-9032-z

Kara, F. M. (2015). Determination Of The Effects Of Leisure Boredom To The Quality Of Life And The Marital Satisfaction (Unpublished doctoral dissertation). Gazi University Department of physical education and sports, Ankara.

Kara, F. M., \& Ayverdi, F. (2018). Is the Leisure Boredom Predictor of Drinking Motives of University Students?. Journal of Gazi physical education and sports sciences, 23(1), 35-42.

Kara, F. M., \& Gücal, A. Ç. (2016). Role of Leisure Boredom in Prediction of Workaholism in Academicians. Başkent University Faculty of Health Sciences journal, 1(1), 48-63.

Kara, F. M., \& Özdedoğlu, B. (2017). Examination of Relationship Between Leisure Boredom and Leisure Constraints, Sport Sciences (NWSASPS), 12(3), 24-36. https://doi.org/10.12739/NWSA.2017.12.3.2B0109

Kara, F. M., Gürbüz, B., \& Öncü, E. (2014). Leisure Boredom Scale: the Factor Structure and the Demographic 
Differences. The Turkish Journal of Sport and Exercise, 16(2), 28-35. https://doi.org/10.15314/TJSE.201428102

Kara, F. M., Gürbüz, B., Küçük-Kılıç, S., \& Öncü, E. (2017). An investigation of physical education pre-service teachers' leisure boredom, life satisfaction and social connectedness levels. International 9. Congress of physical education and sports teaching, Antalya.

Karaküçük, S., \& Akgül, M.B. (2016). Eco Recreation Recreation and Environment (First Ed.), Gazi Kitabevi, Ankara.

Mansuroğlu, S. (2002). Determination of Leisure Characteristics and Outdoor Recreation Tendencies for Students of Akdeniz University. Akdeniz University Faculty of Agriculture Journal, 15(2), 53-62.

McCormick, B. P., Funderburk, J. A., Lee, Y., \& Hale-Fought, M. (2005). Activity characteristics and emotional experience: predicting boredom and anxiety in the daily life of community mental health clients. Journal of Leisure Research, 37(2), 236-253. https://doi.org/10.1080/00222216.2005.11950052

Newberry, A. L., \& Duncan, R. D. (2001). Roles of boredom and life goals in juvenile delinquency. Journal of Applied Social Psychology, 31(3), 527-541. https://doi.org/10.1111/j.1559-1816.2001.tb02054.X

Öner, B. (2017). Studying The Relation Between Sense Of Boredom In Leisure, Internet Addiction And Academic Success Of The Adolescents (Unpublished Master's Thesis). Akdeniz University Institute Of Social Sciences Department Of Recreation, Antalya.

Pekrun, R., Goetz, T., Daniels, L. M., Stupnisky, R. H., \& Perry, R. P. (2010). Boredom in achievement settings: exploring control-value antecedents and performance outcomes of a neglected emotion. Journal of Educational Psychology, 102(3), 531-549. https://doi.org/10.1037/a0019243

Pekrun, R., Goetz, T., Titz, W., \& Perry, R. (2002). Academic emotions in students' self-regulate learning and achievement: A program of qualitative and quantitative research. Educational Psychologist, 37, 91-105. https://doi.org/10.1207/S15326985EP3702_4

Ragheb, M. G., \& Merydith, S. P. (2001). Development and validation of a multidimensional scale measuring free time boredom. Leisure Studies, 20(1), 41-59. https://doi.org/10.1080/02614360122569

Spruyt, B., Vandenbossche, L., Keppens, G., Siongers, J., \& Van Droogenbroeck, F. (2018). Social Differences in Leisure Boredom and its Consequences for Life Satisfaction Among Young People. Springer Science and Business Media Dordrecht, 11, 225-243. https://doi.org/10.1007/s12187-016-9430-y

Tabachnick, B., Fidell, G., \& Linda, S. (2013). Using Multivariate Statistics 6. Bask1, Pearson Education: Boston.

Thackray, R. I. (1981). The stress of boredom and monotony: a consideration of the evidence. Psychosomatic Medicine, 43, 165-176. https://doi.org/10.1097/00006842-198104000-00008

Torkildsen, G. (2006). Leisure and Recreation Management (5th. Ed.), USA: Routledge.

Van Tilburg, W. A. P., \& Igou, E. R. (2012). On boredom: lack of challenge and meaning as distinct boredom experiences. Motivation and Emotion, 36(2), 181-194. https://doi.org/10.1007/s11031-011-9234-9

Vogel-Walcutt, J. J., Fiorella, L., Carper, T., \& Schatz, S. (2012). The definition, assessment, and mitigation of state boredom within educational settings: a comprehensive review. Educational Psychology Review, 24(1), 89-111. https://doi.org/10.1007/s10648-011-9182-7

Wiesner, M., Windle, M., \& Freeman, A., (2005). Work stress, substance use, and depression among young adult workers: An examination of main and moderator effect model. Journal of Occupational Health Psychology, $10,83$. https://doi.org/10.1037/1076-8998.10.2.83

Yaşartürk, F., Akyüz, H., \& Karataş, İ., (2017). Examination of University Students' Levels of Leisure Boredom Perception and Life Satisfaction towards Recreative Activities. International Journal of Cultural and Social Studies, 3, 239-252.

\section{Copyrights}

Copyright for this article is retained by the author(s), with first publication rights granted to the journal.

This is an open-access article distributed under the terms and conditions of the Creative Commons Attribution license which permits unrestricted use, distribution, and reproduction in any medium, provided the original work is properly cited. 